\title{
Antihyperglycemic Activity and Phytochemical Screening of Khaya Senegalensis (Meliaceae) in Wistar Rats
}

\author{
Adeoti Mansour Franck ${ }^{1}$, Gogahy Konan ${ }^{1}$, Monteomo Gnate François ${ }^{1}$, Camara-Cisse Massara ${ }^{2}$, \\ Djaman Allico Joseph ${ }^{3}$, Dosso Mireille ${ }^{4}$ \\ ${ }^{1}$ Medical Biochemistry Laboratory, University Teaching Hospital of Yopougon, Abidjan, Côte d'Ivoire \\ ${ }^{2}$ Medical Biochemistry Laboratory, Medical Sciences of University Felix Houphouēt-Boigny, Abidjan, Côte d'Ivoire \\ ${ }^{3}$ Medical and Basic Biochemistry Laboratory of Pasteur Institute, Abidjan, Côte d'Ivoire \\ ${ }^{4}$ Pasteur Institute, Abidjan, Côte d'Ivoire
}

Email address:

monteomo_gnate@yahoo.fr (M. G. François)

\section{To cite this article:}

Adeoti Mansour Franck, Gogahy Konan, Monteomo Gnate François, Camara-Cisse Massara, Djaman Allico Joseph, Dosso Mireille. Antihyperglycemic Activity and Phytochemical Screening of Khaya Senegalensis (Meliaceae) in Wistar Rats. Advances in Biochemistry. Vol. 4, No. 5, 2016, pp. 53-57. doi: 10.11648/j.ab.20160405.11

Received: August 19, 2016; Accepted: September 9, 2016; Published: October 14, 2016

\begin{abstract}
The aim of this study was to identify the chemical group, evaluate an acute toxicity study and analyze the effect of aqueous extract Khaya senegalensis (Meliaceae), on experimentally induced hyperglycemic condition in rats. The phytochemical study of the aqueous extract of Khaya senegalensis revealed the presence of active secondary metabolic compounds such as flavonoids, polyphenols, catechol tannins, quinones, saponins, sterols and terpenes. The stem bark of Khaya senegalensis was used for acute toxicity study by gavage in Swiss mice. The aqueous extract of Khaya senegalensis (AEKS) at the dose of $35 \pm 5 \mathrm{mg} / \mathrm{kg}$ administrated by gavage showed that all the mice treated were living after 24 hours. The lethal dose obtained by intraperitoneal administration with graded doses to the mice was $1778 \mathrm{mg} / \mathrm{kg}$. This extract could be non-toxic. The study of AEKS activity on blood glucose in rats showed a significant $(p<0.01)$ the concentration of glucose in the serum of the treated rats with the AEKS $(96.2 \pm 30 \mathrm{mg} / \mathrm{dl})$ and Glibenclamide $(92.4 \pm 10 \mathrm{mg} / \mathrm{dL})$, compared to glucose concentrations in the serum of hyperglycemic rats $(197.1 \pm 50 \mathrm{mg} / \mathrm{dl})$. Thus, the study showed hypoglycemic activity of aqueous extract of Khaya senegalensis. In conclusion, the administration of AEKS causes hypoglycemic activity in rats given oral glucose load. Hypoglycemia this is due to the presence of active chemical groups in the extract of this plant, such as flavonoids, catechin tannins, polyphenols, quinones, sterols and terpenes. These results confirm the therapeutic indication in traditional medicine Khaya senegalensis in the treatment of diabetic disease.
\end{abstract}

Keywords: Khaya senegalensis, Phytochemical Screening, Toxicity, Hypoglycemic, Rat

\section{Introduction}

The lack of health coverage in Sub-Saharan countries and the high cost of the annual management of the diabetic patient excluding complications, explain the renewed interest in the traditional [18] medicine. The antidiabetic substances research of plant begun by in vitro methods, in vivo and clinical to develop phytomedicines at affordable prices for the population is booming on all continents. Of all time, plant extracts have been used for the treatment of diabetes in Africa, America, Asia, Australia and Europe [3]. Thus, the existence of a traditional antidiabetic pharmacopeia for the treatment of diabetic pathology is confirmed by traditional healers and medicine [18].

Khaya senegalensis (Meliaceae), is native to tropical Africa. It is found in an area stretching from the Atlantic Ocean to the Indian Ocean by crossing tropical West Africa.

Khaya senegalensis (Meliaceae), commonly known caïcédrat in West Africa, is one of the plants used in the Ivorian pharmacopeia.

The distribution of this tree covers the entire SudanoGuinean climate area and extends slightly north of the SahelSudanese climate where it must find in the soil enough moisture to compensate for the dryness of the atmosphere. It 
accommodates an annual average temperature between $29^{\circ} \mathrm{C}$ and $40^{\circ} \mathrm{C}$ for the warmest month. This species is found in Côte d'Ivoire in Ferkessedougou area and Mali. The caiilcédrat shows an almost permanent leafing. The leaves fall during the dry season but are renewed at soon [11].

It is especially abundant on moist alluvium of river borders and non-flooded lowlands. It grows on moist alluvial lateritic soil and also while keeping a large diameter.

The decoction of the leafy stems or roots used in drink and bath, cures jaundice, hyperthermia and edema widespread [1, 12]. At the current Sudan, traditional healers treat malaria with the extract of Khaya senegalensis trunk bark. In Gambia, the fever is treated with the stem bark of this plant macerated. In Mali, the stem bark decoction is used to treat hemorrhoid bath and diabetes [1, 12].

It is also identified in the aerial parts of the plant hypothermic substances, antibacterial, antipyretic, tonic and anthelmintic [2].

The objective of this preliminary study was to identify both the active chemical groups of the extract aqueous of Khaya senegalensis bark and the toxicity and evaluate its effect on hyperglycemic induced in the Wistar rat.

\section{Materials and Methods}

\subsection{Plant Material and Preparation of Dosage Form}

The plant material used is made of fresh bark of Khaya senegalensis trunk harvested in the forests of Katiola (Côte d'Ivoire) and authenticated National Floristic Center of Felix University Centre Houphouët-Boigny. The aqueous trunk aqueous extract of Khaya senegalensis (AEKS) was prepared from $300 \mathrm{~g}$ of trunk bark powder were introduced into a flask containing 3 liters of distilled water. The decoction was carried out with stirring in a water bath at $100^{\circ} \mathrm{C}$ for 2 hours. After cooling, the decoction was filtered through cotton wool and paper Whatman $\mathrm{N}^{\circ}$. 1; the filtrate obtained was concentrated in a rotary evaporator (Laborata 4000 Heidsph, France) under vacuum at a temperature of $50^{\circ} \mathrm{C}$. After concentration, the filtrate was taken up with a little distilled water and then lyophilized after 48 hours of freezing.

\subsection{Phytochemical Screening}

The phytochemical from the aqueous extract of Khaya senegalensis is a qualitative test to characterize the different chemical groups present in this aqueous extract which present a pharmacological interest. This test identifies the chemical groups or secondary metabolite content in the plant species such as polyphenols, alkaloids, tannins, flavonoids, saponins, quinones, terpenes and sterols and cardiac glycosides. The tests were for compounds of detection methods with the indication of the reagents which are summarized in Table 1.

\subsection{Method of Acute Toxicity Study by Gavage of the AEKS}

\subsubsection{Determination of the Concentration at the Limit of Solubility}

In some distilled water, the dry extract was gradually dissolved until the limit of the solubility to determine the concentration on the limit of solubility or maximal concentration in our study. The solution at the limit of solubility is obtained with $1 \mathrm{~g}$ of lyophilized extract and it needed 4.29 milliliters of distilled water. Of this fact: $\mathrm{Cmax}=$ $0.233 \pm 0.005 \mathrm{~g} / \mathrm{ml}$ soit $233 \pm 5 \mathrm{mg} / \mathrm{ml}$.

\subsubsection{Administration of Dose on the Limit of Solubility or Maximal Dose}

The experimentation consists to divide of 5 random groups of 3 mice. We determine the mortality after 24 hours according the dose during only administration to the animals experiment. Mice did not present signs of infection were put on an empty stomach during 14 hours. The administration is made by oral way in the proportions of $0.6 \mathrm{ml}$ for $20 \mathrm{~g}$ [(14)] weight using a stiff with. This corresponded at the dose $7010 \pm 30 \mathrm{mg} / \mathrm{kg}$ of AEKS. The witness received only distilled water.

$\mathrm{V}$ : Volume administrated to mice was: $\mathrm{V}=0.03 \mathrm{Mml} \mathrm{M}$ : Mass of the mice

\subsection{Animals and Induction of Oral Glucose Tolerance Test}

The antihyperglycemic experiment was conducted on 32 male rats Wistar (Rattus norvegicus) divided into 4 groups of 8 hyperglycemic animals a lot normoglycaemic witness. The animals are kept in pet UFR - Biosciences at room temperature with a stable humidity with a day/night cycle from 12: $12 \mathrm{~h}$. They have free access to water and food.

The hyperglycemia was induced in rats by glucose load $(4 \mathrm{~g} / \mathrm{kg})$ administered 1 hour after gavage of each solution using an esophageal stainless steel.

\subsection{Animal Treatment}

32 male rats weighing on average $185 \pm 10 \mathrm{~g}$, were divided into 4 groups of 8 animals rendered hyperglycemic with a normoglycemic control group that received distilled water.

These animals underwent two types of oral treatments: a single administration to rats of tested solutions (glibenclamide $0.2 \mathrm{mg} / \mathrm{kg} / \mathrm{ov}$; AEKS at $35 \mathrm{mg} / \mathrm{kg} / \mathrm{ov}$ ) a week for 6 weeks and repeated administration in 3 successive days solutions tested per week. Blood samples were taken before administration of extracts and glucose and subsequently at 1 , 2, 3 and 4 hours after.

Blood glucose determination was produced by the enzymatic method with glucose oxidase/peroxidase using the glycemic player One Touch Basic (Lifescan, mulpital, USA) [17]. 
Table 1. Methods of phytochemical screening.

\begin{tabular}{|c|c|}
\hline Materials to search (Reagents used) & Characterization methods (Expected results) \\
\hline Sterols and Polyterpenes & Evaporate $5 \mathrm{ml}$ of the extract in a capsule $+1 \mathrm{ml}$ of acetic anhydride $+0.5 \mathrm{ml}$ sulfuric acid (Ring purple) \\
\hline Flavonoids (cyanidin) & $\begin{array}{l}\text { Evaporate flavonoids } 2 \mathrm{ml} \text { of the extract into a capsule and then cooled, to the residue in } 5 \mathrm{ml} \text { of hydrochloric } \\
\text { alcohol, add } 3 \text { drops of isoamyl alcohol (orange to pink) }\end{array}$ \\
\hline Catechic tannins (Stiany) & $\begin{array}{l}\text { Evaporate } 5 \mathrm{ml} \text { of the extract in a capsule }+15 \mathrm{ml} \text { mixture (formalin } 30 \% \text { and } 30 \% \mathrm{HCl} \text { ), maintain at } 80^{\circ} \mathrm{C} \text { for } 30 \\
\text { min then cool (Rushed into large flakes) }\end{array}$ \\
\hline $\begin{array}{l}\text { Gallic tannins (Sodium acetate Iron } \\
\text { trichloride) }\end{array}$ & $\begin{array}{l}\text { Filter } 5 \mathrm{ml} \text { of the extract in a capsule saturate with sodium acetate Add } 3 \text { drops of iron trichloride to } 2 \% \text { (Intense } \\
\text { blue) }\end{array}$ \\
\hline Quinones (Borntraeger) & $\begin{array}{l}\text { Evaporate } 2 \mathrm{ml} \text { dry extract Triturate the residue add } 5 \mathrm{ml} \text { of } \mathrm{HCl} \text { heated at } 100^{\circ} \mathrm{C} \text { for } 30 \mathrm{~min} \text { cool and add } 2 \mathrm{ml} \text { of } \\
\text { chloroform and } 0.5 \mathrm{ml} \text { of } 50 \% \text { ammoniac (red). }\end{array}$ \\
\hline Alkaloids (Dragendorff-Bouchardat) & $\begin{array}{l}\text { Evaporate } 4 \mathrm{ml} \text { of the extract }+4 \mathrm{ml} \text { of alcohol at } 60^{\circ} \mathrm{C}+2 \text { drops of Reagent-Iodo bismutate (Orange) }+2 \text { drops of } \\
\text { Reagent Iodo-iodized (Brun) }\end{array}$ \\
\hline Saponins & $\begin{array}{l}1 \mathrm{~g} \text { of powder extract Add } 100 \mathrm{ml} \text { of water to a boil for } 15 \text { minutes to cool and filter successively introduce } 1 \mathrm{ml} \text {, } \\
2 \mathrm{ml}, 3 \mathrm{ml} \ldots . .10 \mathrm{ml} \text { of decoction, stir for } 15 \text { seconds, Let stand for } 15 \text { minutes and measure the foam height (Height } \\
\text { of foam equal to } 1 \mathrm{~cm}\end{array}$ \\
\hline Coumarines & $\begin{array}{l}\text { evaporate } 5 \mathrm{ml} \text { of the macerated extract }+2 \mathrm{ml} \text { of hot water }+0.5 \mathrm{ml} \text { of ammoniac hydroxide to } 25 \% \\
\text { (Fluorescence) }\end{array}$ \\
\hline
\end{tabular}

\subsection{Data Statistical Analysis}

Blood glucose values were expressed as mean \pm standard deviation (error) the average. The homogeneity of blood glucose values in each group was verified by the Student test.
The results of the blood glucose levels of the various groups were compared by the Student test. The $(\alpha)$ considered risk ( $p$ $<0.05$ ) determining the significance test, $(\mathrm{n})$ is the number of experiences [10].

\section{Results}

Table 2. Groups active chemical present in the extracts of Khaya senegalensis.

\begin{tabular}{|c|c|c|c|c|c|}
\hline & $\begin{array}{l}\text { Extract } 1 \\
\text { (DCM) }\end{array}$ & $\begin{array}{l}\text { Extract } 2 \\
(\mathrm{meOH})\end{array}$ & $\begin{array}{l}\text { Extract } 3 \\
\text { (Infusion) }\end{array}$ & $\begin{array}{l}\text { Extract } 4 \\
\text { (etOH) }\end{array}$ & $\begin{array}{l}\text { Extract } 5 \\
\text { (Decoction) }\end{array}$ \\
\hline Flavonoïds & + & + & + & + & + \\
\hline Alkaloids & - & - & - & - & - \\
\hline Polyphenols & + & + & + & + & + \\
\hline Catechic tannins & + & + & + & + & + \\
\hline Gallic tannins & - & - & - & - & - \\
\hline Quinones & + & + & + & + & + \\
\hline Sterols et Terpenes & + & + & + & + & + \\
\hline Coumarins & - & - & - & - & - \\
\hline
\end{tabular}

NB: +: Present, -: Absent

Catechin tannins and flavonoids were the most chemical groups present in the bark extracts of Khaya senegalensis. Alkaloids, saponins, gallic tannins and coumarins have not been highlighted in the extracts.

\subsection{Acute Toxicity of Khaya Senegalensis}

Table 3. Changes in the death rate of mice by dose Khaya senegalensis administered orally.

\begin{tabular}{llll}
\hline $\begin{array}{l}\text { Groups of } \\
\text { mice }\end{array}$ & $\begin{array}{l}\text { Decreasing dose } \\
(\mathbf{m g} / \mathbf{k g})\end{array}$ & $\begin{array}{l}\text { Number of } \\
\text { deaths }\end{array}$ & Mortality (\%) \\
\hline 1 & $7010 \pm 30$ & 1 & 20 \\
2 & $3505 \pm 15$ & 1 & 20 \\
3 & $2334 \pm 10$ & 0 & 0 \\
4 & $1752 \pm 7$ & 0 & 0 \\
5 & $1401 \pm 21$ & 0 & 0 \\
\hline
\end{tabular}

The aqueous extract of Khaya senegalensis administered at a dose of $2334 \mathrm{mg} / \mathrm{kg}$ orally did not result in mortality in contrast to the dose of dilute solute $1 / 2$.

\subsection{Antihyperglycemic Activity of Khaya Senegalensis}

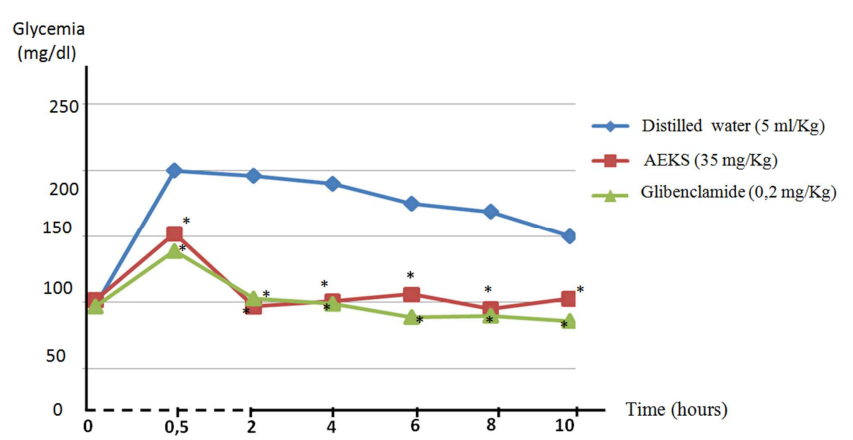

Figure 1. Administration of single tested in hyperglycemic rats.

There is a significant difference in blood glucose $(\mathrm{p}<0.05)$ 
between the control group and treated according batches time either by the aqueous extract of Khaya senegalensis or oral antidiabetic reference (glibenclamide).

\section{Discussion}

The preliminary assay of acute toxicity by gavage shows that the aqueous extract of Khaya senegalensis (AEKS) at the dose of $2334 \pm 10 \mathrm{mg} / \mathrm{kg}$ is not toxic at mice after 24 hours in our study condition (Table 3 ). Indeed, this dose obtained with the maximal concentration of the extract solubility, all the mice Swiss stayed in live. So, the AEKS could not be toxic in reduced dose to that is $35 \pm 5 \mathrm{mg} / \mathrm{kg}$ used by the tradipratician.

The aqueous extract of Khaya senegalensis at the dose 35 $\mathrm{mg} / \mathrm{kg} / \mathrm{ov}$ single dose causes a hypoglycemic action of $33.1 \%$ in a single dose in the second time only after the oral glucose load (fig 1). This observation showed that the hypoglycemic activity of AEKS on a model of hyperglycemia caused orally was short ( 2 hours after a peak of hyperglycemia to the $30^{\text {th }}$ minute). Based on the time of action, could be called Khaya senegalensis of medicinal plant "quick action". Moreover, the results of phytochemical screening AEKS revealed the presence of active chemical groups such as quinones, flavonoids, catechic tannins, polyphenols, sterols and terpenes. These compounds could be causing the observed glucose lowering activity of AEKS.

Indeed, this finding is consistent with results of the work of some authors who have found these active chemicals whose quinones [9] and flavonoids, catechic tannins, polyphenols, quinones, sterols and terpenes $[9,16]$. Thus, an experimental study has demonstrated hypoglycemic activity of polyphenols. In addition, intravenous administration of polyphenols (caffeic acid) is accompanied by a decrease in blood glucose after an oral adminitration glucose load in rats [12]. Such effects could be explained by inhibition polyphenols on glucosidases or glucose transporters at the intestinal barrier, thereby limiting the intestinal absorption of glucose.

Catechin tannins and quinones that we identified in AEKS also have hypoglycemic activity in the ethanol extract $70 \%$ Rauvolfia vomitoria (Apocynaceae) during a adminitration oral glucose load of $4 \mathrm{~g} / \mathrm{kg} / \mathrm{ov}$ among wistar [13] rats. Catechic tannins and quinones exert an effect on liver enzymes stimulating gluconeogenesis [8]. Also, terpenes that we have identified are bioactive compounds found naturally in many plants with known hypoglycemic activity. The charantin, a triterpene isolated from Momordica charantia has a hypoglycemic effect particularly in the type 2 diabetes [5]. Andrographolide (diterpenoid lactone) isolated from Andrographis paniculata also exerts in vitro a significant hypoglycemic activity.

Terpenes would act by lower glucagon secretion and an action on the intake of chemical elements $\left(\mathrm{Cu}^{2+}, \mathrm{Mg}^{2+}\right)$ for the operation of beta cells [8].

Moreover, the therapeutic role antidiabetic flavonoids is undeniable insofar as these molecules inhibit aldose reductase $[7,15]$ enzyme known to catalyze the conversion of glucose to sorbitol, which participates in diabetic complications. Similarly, glycosylation (ability to set glucose) can be attributed to flavonoid glycosides, phenolic compounds that tend to bind oses [4]. The hypoglycemic activity of AEKS aqueous extract, can be explained by the action of secondary metabolites (flavonoids, polyphenols and terpenes) that stimulate the regulation and release of insulin in the pancreas in animals hyperglycemic state for a glucose uptake by muscle tissue of animal [6]. Thus, the aqueous extract of AESK contains pharmacological substances which gave him the hypoglycemic properties. This assumes that the hypoglycemic active molecules of Khaya senegalensis are soluble in water and ethanol, two extraction media commonly used in traditional medicine.

\section{Conclusion}

The phytochemical screening showed in the aqueous extract of Khaya senegalensis the group of flavonoids, tannins catechic, polyphenols, quinones, sterols and terpenes. These active chemical groups no toxic were responsible for the hypoglycemic activity in Wistar rats induced hyperglycemia state. This property would justify its use in traditional medicine in the treatment of diabetes. Other studies are possible for isolated by thin layer chromatography, chemical subgroups active leaders of the hypoglycemic activity of the extract of bark Khaya senegalensis.

\section{References}

[1] Aké AL. Flore de la Côte d'Ivoire: catalogue systématique, biogéographique et cologie. Editions des conservatoires et jardins botaniques. 2001, 1, (57), Genève, p 280-285.

[2] Amiot MJ, Riollet C, Landrier JF. Polyphénols et syndrome métabolique. Médecine des maladies métaboliques, 2009 ; 3,5: 476-482.

[3] Awah PK. Diabète et médecine traditionnelle en Afrique. Soins de santé, Diabetes Voice, 2006; 51, 3: 24-26

[4] Breneton J. Pharmacolgnosie. Phytochimie. Plante médicinales. Paris Lavoisier, 2002; 3: 346-358.

[5] Choudhary SK, Chabra G, Sharma D. Comprehensive evaluation of antihyperglycemic activity off ractionated Momordica charantia seed extractin alloxan-induced diabetic rats. Complem Alternat Med, 2012; 29: 36-50.

[6] Eltayeb GM. Phytochemical Study of the flavonoids of the roots of Khaya senegalensis. Secheresse. URI. hdl. handle.net/. 2007; 123456789/3269.

[7] Goodarzi MT, ZalF, Malakooti M, Safari MR, Sadeghian S. Inhibitory activity off 1 on the lens aldose reductase of healthy and diabetic rats. Acta Med. Iran. 2006; 44,1: 41-5.

[8] Grover JK, Yadav S, Vats V. Medicinal plants of India with antidiabetic potential. J Ethnopharmacol, 2002; 81: 81-100. 
[9] Idu M, Erhabor JO, Oshomoh EO, Ovuakpor Uvo PO. Phytochemical composition and antimicrobial properties of the seeds of Khaya senegalensis (Desc.) A. Juss. J Advanced Botanic and Zoology.2014; V1I4. DOI:10.15297/JABZ. V1I4.03.

[10] Jourdain B. Probabilités et statistiques. Ellipses, 2013; 2 vol. 76-85.

[11] Kerharo J, Adam JC. La pharmacopée sénégalaise traditionnelle: plantes médicinales et tropicales. Paris, Ed Vigot et frère. 1974; 433-435.

[12] Landrault N, Poucheret P, Azay J, Krosniak M, GascF and al. Effect of a polyphenols-enriched Chardonnay white vine in diabetic rats. J. Agric. Food Chem.,2003,51 (1): 311-318.

[13] N'doua LAR, Aoussi S et al. Effets hypoglycemique et antihyperglycemique de l'extrait ethanolique à $70 \%$ de racines de Rauvolfia vomitoria afzel (apocynaceae). Eur Sci J, 2015; 11, 657-711.
[14] Oghenesuvwe EE, Nwoke EE and Lotanna AD. 2014. Guidelines on dosage calculation and stock solution preparation in experimental animals' studies. 2014; 18,4: 100106.

[15] Oyedemi S, Bradley G, Afolayan A. Antidiabetic activities of aqueous stem bark extract of Strychno shenningsii in streptozotocin nicotinamide type 2 diabetic rats. J of Pharmacological research. 2012; 11, 1: 221-238.

[16] Pousset JL. Plantes médicinales d'Afrique, comment les reconnaître et les utiliser? Edi-Sud, 2004; 95-98pp.

[17] Rheney CC, Kirk KK. Performance of three blood glucose meters. Ann pharmacother, 2000; 34 (3) 317-21.

[18] Yangni AA. Valorisation de la médicine traditionnelle africaine en Côte d'Ivoire. Edit: CEDA. 2054; 162-186. 